\title{
遠隔造形システムSmart Prototyping
}

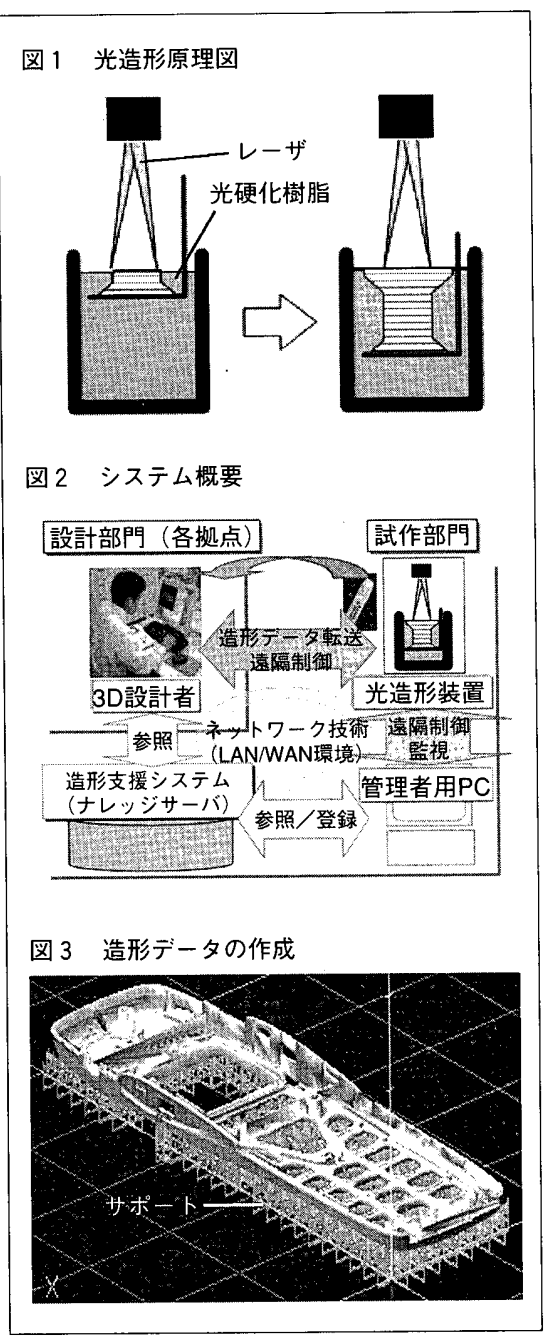

\section{ロはじめに}

近年3D-CADの普及に伴い, 3Dデ ー夕を利用した試作造形Rapid prototypingが利用されるようになってきて いる. 造形装置には光造形や粉末固着 などさまざまな手法を用いたものがあ るが，最近は設計部門をターゲットに した三次元プリンタとして, 省スペー スで，設置環境にも配慮した，卓上型 造形装置も提供されつつある。しかし ながら複雑大型形状で寸法精度が要求 される場合には，専用の設置場所が必 要な光造形装置が一般的に利用されて いる. 光造形法とは, 紫外線などの高 エネルギーレーザの照射により光硬化 樹脂表面を3Dモデルの断面形状に沿 って一層ずつ硬化させて, 順次積層す ることで試作品を造形する方法 (図 1) である。

\section{口課題}

光造形は，レーザ照射などの造形条 件設定や，光造形独自のモデルを保持 するサポートデータの作成にノウハウ や専任作業者が必要であるままた，導 入費用が高価であるため, 設計部門ご との設備導入は容易ではなかった. そ のため光造形装置を所有している社内 外の業者や部門に造形を依頼してお り, 急な設計変更, デー夕受渡しなど で時間ロスが発生する。設計開発を効 率化する上で，設計者の望む夕イミン グで造形できることが求められてい た。

\section{口開発目標}

そこで，造形装置を保有しない部署 の設計者が，おのずから試作品をプロ ットアウト感覚でいつでも手軽に造形 できることを目標に遠隔制御造形シス テムSmart Prototypingを開発した。

\section{Dmart Prototypingの概要}

Smart Prototypingは図 2 に示すよ うに社内LAN/WAN環境をベースに， ネットワーク技術を利用して社内各拠 点の設計部門の $3 D$ 設計者の端末から試 作部門にある造形装置を遠隔制御・監 視できる構成としている，また，個人 レベルの暗黙知と組織レベルの形式知 の相互作用によって知識創造がなされ るという“知識創造理論”(1)に基づい て，熟練技術者の造形ノウハウを抽出 及びデータベース化して設計者に理解 しやすい形で提供する造形知識支援シ ステムも構成の一部に組み込まれてい る、設計者は，造形時のモデルを保持 するサポートが付加された造形データ （図 3 ）を，3D-CADデータから専用 の簡易データ作成ソフトで作成する。 簡易デー夕作成ソフトは，造形の専門 知識をあまり持たない設計者でも，造 形ノウハウが反映された造形デー夕を 簡単な操作で作成しやすいようにして いる．作成された造形データはネット ワーク経由で装置へ転送され, 通常は 造形装置側で行う造形モデル配置や造
形パラメー夕設定作業を，設計者の端 末上で行った後に，遠隔制御で造形を 開始する。造形終了後は, 試作部門で 造形物を取り外して，社内各拠点の設 計者に配送する。

ここで光造形技術者を配備していな い遠隔地の各設計拠点の3D設計者が, 手軽に熟練者並みの造形を可能とする 技術伝承のために，デー夕作成や装置 制御に必要な知識やノウハウを，熟練 度に応じて段階的に提供できるWebを 利用した電子マニュアル造形知識支援 システムを参照することで獲得できる ようにした。

またシステム管理者は出張などで遠 隔地にいても，モバイルPCなどで造 形経過を監視カメラや造形装置側PC にアクセスして確認できるので, 装置 トラブル発生時の遠隔メンテナンスも 可能である.

\section{口诘景}

社内複数の $3 \mathrm{D}$ 設計部門に本システ ム使用環境を整備し, 評価を兼ねて運 用を行っている. 光造形が未経験の $3 \mathrm{D}$ 設計者に適用した結果, 従来光造 形技術者の育成に長期間要していた が，今回構築した造形知識支援システ ムを半日講習ののち活用することで, 最初からほぼ問題のない造形が可能と なった。設計部門に造形装置がなく， 造形技術の専門知識を持っていない設 計者でも，端末から手軽に試作品の造 形ができるため, 設計期間の短縮など に貢献できた。

\section{おわりに}

製品開発力の向上のためには試作造 形Rapid prototypingの活用は重要で あり，今後とも本システムのような設 計部門が主導で試作造形できるシステ 么の開発が望まれると考える。

（原稿受付 2003年8月4日）

〔木原 均 . 三洋電機 (株)]

\footnotetext{
（1）野中郁次郎・ほか，知識創造企業，（1996）, 東洋経済新報社。
} 